\begin{tabular}{c} 
Volume and Issues Obtainable at Center for Sustainability Research and Consultancy \\
Journal of Accounting and Finance in Emerging Economies \\
ISSN: 2519-0318 ISSN (E) 2518-8488 \\
Volume 6: Issue 1 March 2020 \\
CSRᄃ \\
Journal homepage: www.publishing.globalcsrc.org/jafee \\
\hline
\end{tabular}

\title{
Capital Structure Theories and Speed of Capital Adjustment towards Target Capital Structure along Life Cycle Stages of Asian Manufacturing Firms
}

\author{
${ }^{1}$ Muhammad Sajid Amin, ${ }^{2}$ Hashim Khan, ${ }^{3}$ Imran Abbas Jaddon, ${ }^{4}$ Muhammad Tahir \\ ${ }^{1}$ PhD Research Scholar, Faculty of Management Sciences, COMSATS University Islamabad, Pakistan: \\ sajid.amin719@gmail.com \\ ${ }^{2}$ Assistant Professor, Faculty of Management Sciences, COMSATS University Islamabad, Pakistan: \\ hashim.khan@comsats.edu.pk \\ ${ }^{3}$ Assistant Professor, Faculty of Management Sciences, COMSATS University Islamabad, Pakistan: \\ imran.jadoon@comsats.edu.pk \\ ${ }^{4}$ Assistant Professor, Faculty of Management Sciences,COMSATS University Islamabad, Pakistan: \\ m_tahir@comsats.edu.pk
}

\begin{tabular}{l} 
ARTICLE DETAILS \\
\hline History \\
Revised format: February 2020 \\
Available Online: March 2020
\end{tabular}

\section{Keywords}

Capital Structure Theories, Life

Cycle Stages, Speed of

Adjustment, Market Leverages

JEL Classification:

G32, G39, D91

\begin{abstract}
Firms have different costs and benefits and asymmetric information across their life cycle stages and hence each stage has different financial pattern and speed of adjustment towards target capital. We use System GMM to test the hypotheses. We use market leverages proxies for the capital structure, life cycle proxies: introduction, growth, mature, shakeout and decline and the control determinants of capital structure such as profitability, tangibility, firm size and growth opportunities. We estimate the financial pattern and speed of adjustment along life cycle stages of manufacturing firms from eleven Asian economies over the period of 2010-2018. The results show that firms in earlier stages have more long term debt than mature stage. The speed of adjustment towards target capital structure is highest in mature stage than the other stages. The control determinants significantly affect market leverages.The findings suggest that management has to consider life cycle stages of their firms in order to adjust capital structure. Stockholders should consider stage of firm with relation to profitability and capital structure for long term prospects.
\end{abstract}

\section{OPEN ACCESS}

(C) 2020 The authors, under a Creative Commons Attribution-Non

Commercial 4.0

Corresponding author's email address: sajid.amin719@gmail.com

Recommended citation: Amin, M. S., Khan, H., Jaddon, I. A. \& Tahir, M., (2020). Capital Structure Theories and Speed of Capital Adjustment towards Target Capital Structure along Life Cycle Stages of Asian Manufacturing Firms. Journal of Accounting and Finance in Emerging Economies, 6 (1), 53-62

DOI: $10.26710 /$ jafee.v6i1.1048

\section{Introduction}

There are well documented studies that firms in different industry behave differently. Even, the firms from same industry have different financial constraints (Flannery and Hankins (2007) and Dickinson (2011)). These financial constraints may be the cause and effects of firm and country institutions. The 
firms formulate financial policies particular for equity/debts or by combination of both within these constraints. Being an emerging concept in literature of capital structure, firm life cycle stages (LCS, hereafter LCS) has variant impacts on the speed of adjustment (SOA, hereafter SOA) towards target capital because firm's resources are quite different during its LCS. The literature provides very fewer evidences in this context like cost of equity variations along LCS (Hasan, Hossain, and Habib (2015), formulations of corporate policies with predefined pattern of life cycle (Faff, Kwok, Podolski, and Wong (2016)) and organizational capital along LCS by Hasan and Cheung (2018).

Life cycle has important role in determining firm's capital structure. Each stage of life cycle has different financial costs, benefits and asymmetric information, therefore, it is expected that stages have different SOA. Financial policies of Asian firms differ from western firms'. Firms from developing economies have more short term debts than long term debts as compared to advanced economies' (Booth et al. (2001)). Therefore, we use total market debt ratio in exploring financial pattern and SOA for Asian manufacturing firms along LCS.

As per our best knowledge, it is the first empirical study that captures the financial pattern and SOA along LCS. We have two major objectives in Asian setting: First, empirically investigate pattern of financial leverage along LCS. Second, empirically estimate and compare SOA towards target capital structure along LCS.

\section{Literature Review and Hypotheses}

Static trade off theory (TOT, hereafter TOT) argues that firms adjust capital structure towards target in absence of costs. Pecking order theory (POT, hereafter POT) argues that firms have no specific target capital but firms track on predefined preferences of financing. The dynamic trade off model takes practical implications to adjust capital structure like adjustment costs. Modified POT supports soft target capital structure views and argues that firms adjust it by considering adjustment and disequilibrium costs.

Static TOT framework demands firms should seek tradeoff between debt tax shields against financial distress and bankruptcy costs. Modigliani and Miller are pioneers of this theory. They put two contradict views related to capital structure and firms' value. First, Modigliani and Miller (1958) argue that market worth of any firm is not related to its capital structure. Second, Modigliani and Miller (1963) theoretically argue that capital structure impacts the firms' value. Hirshleifer (1966) and Kraus and Litzenberger (1973) criticize Modigliani and Miller(1958, 1968) postulates on certain earnings' assumptions and argue that optimal financial structure seeks trade-off debt tax shields against bankruptcy costs. Therefore, the growing literature on dynamics of capital structure criticizes traditional capital structure models which do not give considerations to capital structure dynamics. The partial adjustment model is dynamic. Partial adjustment model implies that capital structure for each period is determined with comparison of observed capital structure to target one. Fischer, Heinkel, and Zechner (1989) find that transaction costs direct firms' financing policies regularly. Goldstein, Ju, and Leland 's (2001) study concludes retiring debt costs have a tendency for the firms to adjust leverage. Hennessy and Whitted's (2005) study of dynamic trade off model concludes that proportional floatation costs cause to increase equity issuance costs.

Myers (1984) criticizes Donaldson (1961) on the absence of target capital in his pecking order model. He proposes another version of POT by incorporating asymmetric information effects, floating costs and costs of financial distress. He identifies that asymmetric information produces different costs and firm may or may not issue new securities. He suggests that firm issues (purchases) new (outstanding) equities when its existing securities are overvalued (undervalued) and known as market timing theory. The investor perceives positive (negative) signal when firm launches new debt (stock). They perceive debt issuing firm has ability to repay its debt obligations in future and equity issuing firm going to catch opportunity of overvalued stock (known as signaling effect). Adverse selection depends on nature of asymmetric information related to firm's value or related to firm's risks. Managers prefer retained 
earnings to avoid adverse selection related to firms' value and they prefer to issue equity in case of risks. Byoun (2008) observes adverse selection in his capital structure model.

Few empirics classify firms into categories like small and large, dividend paying and non paying Byoun (2008) and Faulkender et al. (2012)) and young and fast growing firms (Flannery and Rangan (2006)) to estimate and compare SOA. Kieschnick and Moussawi (2018) find that debt is inversly related with LCS. Berger and Udell's (1998) study growth of firms and identify the avaialblity of financing and its costs depend on LCS. Dickinson (2011)1 defines firm as a portfolio of multi-products in multi-industries. Each product has distinct stage of life cycle. Therefore, it is hard to capture LCS at firm level. She argues financing, investing and operating cash flow patterns associate with LCS as a non-sequential approach. She classifies firms' life cycle into introduction, growth, mature, shake out and decline stages.

Benefits and costs of debt vary along LCS and TOT addresses this nexus. Such as growing/mature firms have more profits, more tangible assets and larger diversified size to avoid financial and bankruptcy costs (Castro et al. (2016) and Fan et al. (2012)). The information asymmetric varies across LCS and POT discusses this nexus. It is higher at introduction and growth than maturity stage. Mostly, the firms opt for equity financing during introduction stage, growing and mature stages retain more earnings from profits to finance growth prospects. Firms use less debt with higher profits and larger size. Myers (1984) finds that adjustment costs create lags between target capital and actual debt ratio. Fischer et al. (1989) identify that fixed costs let firm to rebalance capital structure only when it deviates from a specified lower/upper limit. Shyam-Sunder and Myers (1999) find validation of POT in adjusting target capital. Byoun (2008) and Hovakimian and $\mathrm{Li}$ (2009) find that asymmetric adjustment costs relate to target capital structure.

By summing up the above discussion, TOT seeks balancing of benefits against costs of debt in adjusting capital structure. Therefore, benefits and costs of debt financing are likely change across life cycle and TOT addresses this nexus. POT argues that information asymmetric varies across firms and over time. We expect that asymmetric information is higher at introduction and growth stages than maturity stage.

Introduction stage has deficit knowledge of potential costs and revenues, investment in projects are high and need more debt to grow. Growth and maturity stages have less deficit knowledge of potential costs and revenues, potential increase in investment and efficiency, investment in projects are higher in both stages. Growth stage needs more funds to finance projects while mature stage engages in repay debts and/or repurchase equity. Decline stage is characterized with declining in prices and growth rates, liquidate assets to pay debt obligations and keeps focus on renegociate debt. In order to shed light on financial leverage and its associated prospects, we investigate Asian firms' capital structure behavior across different LCS. We develop following hypothesis.

H1: Firms have comparatively higher debt ratio in earlier stages than maturity as they move from introduction to mature stage

Hovakimian et al. (2001) finds firms have different SOA from each other and over the period. Faulkender et al. (2012) identify firms adjust capital structure in two ways. First, when benefits are leftover costs and secondly when adjustment costs are relatively low. Small firms are exposed to problem of information asymmetry and have to bear higher cost of financing (debt or equity). Moreover, empirics highlight that firms with higher profitability, less financial leverage and mature in nature are likely to issue debt because they have more incentives in issuing debt (Huang and Ritter (2009)). Firms having growth prospects are always in need to finance their growth prospects; hence, they issue equity financing because it is less constraint. Moreover, TOT explains that high leveraged firms always prefer equity funding to avoid

1 See for detail: Dickinson, V. (2011). Cash flow patterns as a proxy for firm life cycle. The Accounting Review, 86(6), 1969-1994 
constraints of collateral attached to debts. Firms in mature stage have growth prospects and mostly have a significant portion of retained earnings. The growth prospects and based on the above views, we construct following hypothesis:

H2: The firms in mature stage have higher SOA than earlier stages introduction and growth and later stage decline.

We use determinants of capital structure like profitability, size, asset tangibility and growth prospects as control variables to justify POT and TOT. Firms are exposed with higher profitability are more likely to finance through retain earning and less reliance on debts. Firms with greater market capitalization enjoy easy access of equity financing. Tangibility floats good signal into market for issuing equities and ensures that firms' have enough collateral values. High market to book ratio is signal of superior performance of assets in place. Based on these views, we expect the negative relationship between financial leverage and firm's tangibility, profitability, size and positive relationship with growth opportunities under the POT. Dynamic TOT implies that more profitable firms have fewer probabilities of financial distress and bankruptcy. These are capable to serve the financial obligations. Firms with greater market capitalization enjoy easy access of debt finance because larger firms are stable and are less likely to be bankrupt. This theory deems that growth opportunities are intangible assets and have no collateral value. Firms with higher tangible fixed assets have more collateral value and simple approach to debt. Based on these views, we expect the negative relationship between financial leverage and growth opportunities and positive relationship with profitability, tangibility and size under the TOT.

\section{Methodology}

\subsection{Sample}

We use firm specific data of eleven Asian countries obtained from OSIRIS over period of 2010-2018. We focus on manufacturing firms drawn from Japan, Pakistan, Sri Lanka, Indonesia, India, South Korea, Singapore, Malaysia, Turkey, Thai Land and Philippine. We follow Dickinson (2011) for data generating process.

\subsection{Variables Definition}

The table 1 presents variables measurement. Market leverages reduce countries differences and manipulations (Booth et al. (2001)). Further Dickinson (2011) argues that her classification of life cycle proxies better explain the rates of return and stock returns. Therefore, this study prefers market leverage proxies.

\subsection{Model Specification}

We have short panel data set. Therefore, we expect variations between groups dominates the variations within the groups. In addition to, we use lagged dependent variable as independent variable. Therefore, partial adjustment model is suitable. The model specification is as follow:

$$
\begin{gathered}
\operatorname{Mlev}_{\mathrm{i}, \mathrm{t}}=(1-\delta) \operatorname{Mlev}_{\mathrm{i}, \mathrm{t}-1}+\left(\delta \alpha_{\mathrm{i}}\right) \mathrm{Z}_{\mathrm{i}, \mathrm{t}}+\mathrm{bi} \sum_{\mathrm{k}=1}^{\mathrm{m}} \mathrm{LC}_{\mathrm{k}}+\mathrm{ci} \sum_{\mathrm{k}=1}^{\mathrm{m}} \mathrm{LC}_{\mathrm{k}} * \mathrm{Mlev}_{\mathrm{i}, \mathrm{t}-1}+\sum_{\mathrm{k}=1}^{\mathrm{m}} \mathrm{ID}_{\mathrm{k}}+ \\
\sum_{\mathrm{k}=1}^{\mathrm{m}} \mathrm{CD}_{\mathrm{k}}+\sum_{\mathrm{t}=2011}^{2018} \mathrm{TM}_{\mathrm{t}}+\varepsilon_{\mathrm{i}, \mathrm{t}}
\end{gathered}
$$

$\mathrm{Mlev}_{\mathrm{i}, \mathrm{t}}$ represents market debt ratios in terms of long term debts and total debts. $(1-\delta) \mathrm{Mlev}_{\mathrm{i}, \mathrm{t}-1}$ represents lagged value of market leverages and $\left(\delta \alpha_{\mathrm{i}}\right) \mathrm{Z}_{\mathrm{i}, \mathrm{t}}$ is a vector of control determinants. $\sum_{\mathrm{k}=1}^{\mathrm{m}} \mathrm{LC}_{\mathrm{k}}$, $\sum_{\mathrm{k}=1}^{\mathrm{m}} \mathrm{ID}_{\mathrm{k}}$ and $\sum_{\mathrm{t}=2010}^{2018} \mathrm{TM}_{\mathrm{t}}$ are set of dummies for $\mathrm{LCS}$, industries and years respectively. $\sum_{\mathrm{k}=1}^{\mathrm{m}} \mathrm{LC}_{\mathrm{k}} *$ $\mathrm{Mlev}_{\mathrm{i}, \mathrm{t}-1}$ represents a vector of interaction terms between $\mathrm{Mlev}_{\mathrm{i}, \mathrm{t}-1}$ and the dummy of LCS. The coefficients of dummies bi capture the differences in means of LCS and 1- $\delta$ - $c i$ captures the SOA; where $\delta$ is coefficient of $\mathrm{Mlev}_{\mathrm{i}, \mathrm{t}-1}$ and ci is the coefficient of interaction terms. 
The sys-GMM performs better to estimate the equation I (Deesomsak et al. (2004) and Antoniou et al. (2008)). We apply pre-diagnostic tests such as Wooldridge, White /Koenker and Wu-Hausman to check autocorrelation, heteroskedasticity and endogeneity for suitability of GMM. We also apply post diagnostic tests such as $\mathrm{AR}(1)$ and $\mathrm{AR}(2)$ to check autocorrelation, Hanen's J-test to check instruments validity and Wald test to check the goodness of model.

Table 1: Capital Structure and its Determinants

\begin{tabular}{|l|l|l|}
\hline $\begin{array}{l}\text { Independent } \\
\text { Variables }\end{array}$ & Proxy/ Measurement & Empirics \\
\hline $\begin{array}{l}\text { Total market } \\
\text { leverage }\end{array}$ & $\begin{array}{l}\text { Total book debt / (Total debt plus market } \\
\text { value of equity (share price x number of } \\
\text { outstanding shares) }\end{array}$ & $\begin{array}{l}\text { Hovakimian et al. (2001), Antoniou et al. } \\
\text { (2008), Byoun (2008), Huang and Ritter } \\
\text { (2009), Fan et al. (2012) and Matemilola et } \\
\text { al. (2018) }\end{array}$ \\
\hline $\begin{array}{l}\text { Long term } \\
\text { market } \\
\text { leverage }\end{array}$ & $\begin{array}{l}\text { Long term book debt / (Long term book } \\
\text { debt plus market value of equity(share } \\
\text { price x number of outstanding shares) }\end{array}$ & $\begin{array}{l}\text { Booth et al. (2001), Byoun (2008), Fan et } \\
\text { al. (2012) and Matemilola et al. (2018) }\end{array}$ \\
\hline $\begin{array}{l}\text { Profitability } \\
\text { Earnings before interest and taxes(EBIT) / } \\
\text { Total assets }\end{array}$ & $\begin{array}{l}\text { Matemilola et al. (2018), Byoun (2008), } \\
\text { Antoniou et al. (2008) and Flannery and } \\
\text { Rangan (2006) }\end{array}$ \\
\hline $\begin{array}{l}\text { Growth } \\
\text { opportunities }\end{array}$ & $\begin{array}{l}\text { Market value of share / Book value of } \\
\text { share (MB) }\end{array}$ & $\begin{array}{l}\text { Matemilola et al. (2018), Huang and Ritter } \\
\text { (2009), Flannery and Rangan (2006), Myers } \\
\text { (1984) and Hasan and Cheung (2018) }\end{array}$ \\
\hline Tangibility & $\begin{array}{l}\text { Net property, plants and equipment (PPE) / } \\
\text { Total assets }\end{array}$ & $\begin{array}{l}\text { Matemilola et al. (2018), Fan et al. (2012), } \\
\text { Byoun (2008) and Booth et al. (2001) }\end{array}$ \\
\hline Size & Natural logarithm of market capitalization & $\begin{array}{l}\text { Dickinson (2011) and Hasan and Cheung } \\
\text { (2018) }\end{array}$ \\
\hline
\end{tabular}

Source: Author's Compilations

\section{Results and Discussion}

\subsection{Descriptive Statistics}

Firms in mature stage are stable and in decline stage are transitory (Dickinson (2011)). Therefore, we expect highest (lowest) rate of recurrence of observations in mature (decline) stage. Table 2 confirms this prediction and finds 58.04 (4.15) percent of firm-observations lie in mature (decline) stage. The mature firms have lower debt as compared to earlier stages.

Table 2: Life Cycle Stages Wise Data Distribution and Means of Debt Ratios

\begin{tabular}{|l|l|l|l|l|l|}
\hline Sr. no & Stages & $\begin{array}{l}\text { Number of } \\
\text { observations }\end{array}$ & $\begin{array}{l}\text { Percent } \\
(\%)\end{array}$ & $\begin{array}{l}\text { Total market } \\
\text { debt ratio }(\%)\end{array}$ & $\begin{array}{l}\text { Long term market } \\
\text { debt ratio (\%) }\end{array}$ \\
\hline 1 & Introduction & 1,876 & 7.34 & 45.28 & 23.67 \\
\hline 2 & Growth & 4,886 & 19.12 & 38.40 & 23.71 \\
\hline 3 & Mature & 14,831 & 58.04 & 26.05 & 14.68 \\
\hline 4 & Shake-out & 2,897 & 11.34 & 26.08 & 13.42 \\
\hline 5 & Decline & 1,061 & 4.15 & 32.80 & 15.99 \\
\hline Total/Pooled & & & 100.00 & 30.11 & 16.98 \\
\hline
\end{tabular}




\subsection{Regression Results}

The results of leverage pattern along LCS are presented in table 3 and SOA in table 4. The significance of Wooldridge test, White /Koenker test and Wu- Hausman test indicate that GMM estimator is suitable for the study.

As per findings of the study (refer to table 3), the findings are consistent with hypothesis 1 that predicts firms' financial leverage is on higher side in other stages when compare to maturity stage. The mature stage is positively associated with firm's leverage $(\beta=0.0295$ and $p<0.05)$. The growth and introduction stages are positively associated with $\beta=0.0476$ and $\beta=0.047$ respectively at $p<1 \%$, the shakeout stage is negatively associated $(\beta=0.0065$ and $p<1 \%)$ and decline stage is $1.6 \times 10^{\wedge}-5$ and negatively insignificant. Mature firms repay debts and growing firms acquire more debt to finance their projects. This is consistent with hypothesis 1; firms are more leveraged as they move from introduction stage to mature stage and less leveraged in shakeout and decline stage. We do not find non monotonic association between LCS and total market leverage (refer to table 3). The findings are contradict with hypothesis 1 which predicts that firms in mature stage have lower financial leverage as compared to earlier stages. The reasons of the contradiction may be that firms in mature stage need more short term debt for working capital. Further, mature firms are more dividend paying and retain lower out of earnings than firms in other stages.

Table 3: Results of System GMM's: Pattern of Financial Leverage along LCS

\begin{tabular}{|c|c|c|c|c|}
\hline & \multicolumn{2}{|c|}{ Long term market leverage } & \multicolumn{2}{|c|}{ Total market leverage } \\
\hline & Coefficients & Z-statistics & Coefficients & Z-statistics \\
\hline Leverage(t-1) & $.7775 * * *$ & $(14.80)$ & $.8287 * * *$ & $(31.47)$ \\
\hline Introduction & $.047 * * *$ & $(12.83)$ & $.0803 * * *$ & $(23.90)$ \\
\hline Growth & $.0476 * * *$ & $(23.50)$ & $.0602 * * *$ & $(34.11)$ \\
\hline shake out & $-.0065 * * *$ & $(-2.92)$ & $-.0106 * * *$ & $(-5.02)$ \\
\hline Decline & -.000016 & $(-0.000)$ & .0022 & $(0.50)$ \\
\hline Profitability & $-.1945 * * *$ & $(-7.24)$ & $-.2535 * * *$ & $(-10.86)$ \\
\hline Size & .00021 & $(0.35)$ & $-.003 * * *$ & $(-3.40)$ \\
\hline Tangibility & $.070 * * *$ & $(3.39)$ & $.0415 * * *$ & $(3.91)$ \\
\hline Growth opportunities & $-.0036 * * *$ & $(-3.47)$ & $-.0052 * * *$ & $(-6.45)$ \\
\hline Constant & $.0295 * *$ & $(2.26)$ & $.0974 * *$ & $(5.38)$ \\
\hline Year/industry/Country effects & Yes & & Yes & \\
\hline No. of groups & 2835 & & 2835 & \\
\hline No. of instruments & 46 & & 46 & \\
\hline $\mathrm{AR}(1) \mathrm{p}$ value & 0.00 & $(-12.44)$ & 0.00 & $(-17.81)$ \\
\hline $\mathrm{AR}(2) \mathrm{p}$ value & 0.502 & $(0.67)$ & 0.172 & $(1.37)$ \\
\hline Hansen test $p$ value & 0.439 & $(0.60)$ & 0.933 & $(0.01)$ \\
\hline Wald chi square & 0.00 & $(17006.61)$ & 0.00 & $(49322.70)$ \\
\hline Wooldridge test P-value & 0.00 & $(1013.47)$ & 0.00 & $(1214.331)$ \\
\hline Wu-Hausman test P-value & 0.00 & $(26.4657)$ & 0.00 & $(71.1933)$ \\
\hline White/Koenker test P-value & 0.00 & $(2020.430)$ & 0.00 & $(1185.359)$ \\
\hline
\end{tabular}

The table 4 presents results of SOA along LCS. The coefficients of Leverage $(\mathrm{t}-1)$ and interaction variables explain the costs of adjustment towards target capital. Higher costs of adjustment slower down adjustment speed towards target capital. The reference category among LCS is mature stage. The incremental adjustment costs for introduction, growth and decline stages are $0.1462,0.1538$ and 0.128 respectively as compared with mature stage. The interaction variables are positively significant and reflect that these stages have lower adjustment towards target capital structure as compared to mature stage. The 
SOA of mature stage is $32.55 \%(1-0.6745)$ per year and for introduction, growth and decline stages are $17.93 \%, 17.17 \%$ and $19.75 \%$ per year respectively.

As concerned with total market leverage, the introduction, growth and decline stages have $0.0448,0.0843$ and 0.1238 higher adjustment costs respectively than mature stage and hence slower SOA towards target as compared to mature stage. The mature stage has SOA 25.13\% (1-0.7487) that is greater than introduction $20.65 \%$, growth $16.70 \%$ and decline $12.75 \%$ stages. Both results support the hypothesis 2 that firms in mature stage have higher SOA than other the stages of life cycle. The empirics on TOT and POT find that adjustment costs and asymmetric information do matter for the firms in determining how they quickly adjust their capital structure (Myers (1984), Hovakimian et al. (2001), Faulkender et al. (2012), Leary and Roberts (2005) and Flannery and Rangan (2006) support TOT hypothesis and Byoun (2008) and Huang and Ritter (2009) support Pecking order hypothesis).

The results show that growth opportunity and profitability have negative significant impacts on capital structure and are similar to the findings of Byoun (2008) and Flannery and Rangan (2006). Tangibility has positive significant impact and findings are in line with Matemilola et al. (2018), Byoun (2008) and Fan et al. (2012).

Table 4: Results of the System GMM's: SOA along the LCS

\begin{tabular}{|c|c|c|c|c|}
\hline & \multicolumn{2}{|c|}{ Long term market leverage } & \multicolumn{2}{|c|}{ Total market leverage } \\
\hline & Coefficients & Z- statistics & Coefficients & Z- statistics \\
\hline Leverage(t-1) & $.6745 * * *$ & $(20.96)$ & $.7487 * * *$ & $(35.42)$ \\
\hline Introduction & $.017 * *$ & $(2.51)$ & $.0667 * * *$ & $(7.66)$ \\
\hline Growth & $.0163 * * *$ & $(2.84)$ & $.0326 * * *$ & $(5.25)$ \\
\hline Shakeout & $-.0238 * * *$ & $(-4.74)$ & $-.0398 * * *$ & $(-7.15)$ \\
\hline Decline & $-.0256 * *$ & $(-3.62)$ & $-.0416 * * *$ & $(-5.01)$ \\
\hline Leverage(t-1)x (introduction) & $.1462 * *$ & $(4.80)$ & $.0448 * *$ & $(2.10)$ \\
\hline Leverage(t-1)x (growth) & $.1538 * * *$ & $(5.47)$ & $.0843 * * *$ & $(4.58)$ \\
\hline Leverage(t-1) x (shake out) & $.0961 * * *$ & $(3.24)$ & $.0921 * * *$ & $(5.29)$ \\
\hline Leverage(t-1) x (decline) & $.128 * *$ & $(3.62)$ & $.1238 * * *$ & $(5.47)$ \\
\hline Profitability & $-.2276 * * *$ & $(-11.41)$ & $-.2934 * * *$ & $(-14.76)$ \\
\hline Size & -.00036 & $(-0.62)$ & $-.004 * * *$ & $(-6.13)$ \\
\hline Tangibility & $0886 * * *$ & $(8.64)$ & $.0577 * * *$ & $(7.28)$ \\
\hline Growth opportunities & $-.0041 * * *$ & $(-7.53)$ & $-.006 * * *$ & $(-9.42)$ \\
\hline Constant & $.0533 * * *$ & $(4.76)$ & $.1382 * * *$ & $(9.72)$ \\
\hline Year/industry/Country effects & Yes & & Yes & \\
\hline No. of groups & 2835 & & 2835 & \\
\hline No. of instruments & 51 & & 51 & \\
\hline $\mathrm{AR}(1) \mathrm{p}$ value & 0.00 & $(-16.73)$ & 0.00 & $(-20.61)$ \\
\hline $\mathrm{AR}(2) \mathrm{p}$ value & 0.550 & $(0.60)$ & 0.173 & $(1.36)$ \\
\hline Hansen test $p$ value (chi statistics) & 0.735 & $(0.62)$ & 0.545 & $(1.21)$ \\
\hline Wald $p$ value & 0.00 & $(29641.74)$ & 0.00 & $(81464.77)$ \\
\hline Wooldridge t P-value & 0.00 & $(862.689)$ & 0.00 & $(1160.955)$ \\
\hline Wu-Hausman P-value & 0.00 & $(22.828)$ & 0.00 & $(76.6671)$ \\
\hline White/Koenker P-value & 0.00 & $(1040.787)$ & 0.00 & $(1251.963)$ \\
\hline
\end{tabular}




\section{Conclusion}

Our findings show that firms in earlier stages of life cycle have comparatively more debt than the firms in mature stage. Moreover, the study also depicts that firm in the mature stage of their life cycle have fastest speed of adjustment followed by introduction and growth stages respectively. The results of total market leverage depict that firms in mature stage have comparatively more debt than other stage, implying that firms in emerging economies heavily rely on debt even in the mature stage which contradict the earlier finding based on long term market leverage. However, the findings in respect of SOA are quite similar as depicted in first proxy of the capital structure.

Our study adds knowledge in context of changing pattern of capital structure along LCS. Secondly, we fill research gap by determining SOA along LCS particularly in Asian context. The Asian manufacturing firms follow pecking order hypothesis that they mainly finance their projects from their profitability and trade off hypothesis for growth prospects, size and tangible assets.

The findings suggest that management has to consider LCS of their firms in order to adjust capital structure. The findings of current study may help stockholders to consider stage of firm with relation to profitability and capital structure for long term prospects. The policy maker may design policy rates that may be supportive for introduction and decline stages. Further, they should develop capital structure bench mark for adjusting capital structure along LCS.

The results of the study cannot be applicable to other industries like services. Future research may be conducted by using larger sample from other industries such as services and economies from regions other than Asia. Speed of adjustment may be estimated across life cycle by using the country specific macro and institutional determinants like GDP growth, interest rates, taxation and etc.

\section{References}

Antoniou, A., Guney, Y., \& Paudya, K. (2008). The Determinants of Capital Structure: Capital Market-Oriented versus Bank-Oriented Institutions. The Journal of Financial and Quantitative Analysis , 43 (1), 59-92.

Berger, A. N., \& Udell, G. F. (1998). The economics of small business finance: The roles of private equity and debt markets in the financial growth cycle. Journal of Banking \& Finance, 22 (6-8), 613-673.

Booth, L., Aivazian, V., Kunt, A. D., \& Maksimovic, V. (2001). Capital Structure in Developing Countries. The Journal of Finance, 56 (1), 87-130.

Byoun, S. (2008). How and When Do Firms Adjust Their Capital Structures toward Targets? The Journal of Finance, 63 (6), 3069-3096.

Castro, P., Fernándeza, ,. M., \& Miguel, A. d. (2016). Target leverage and speed of adjustment along the life cycle of European listed firms. BRQ Business Research Quarterly, 19, 188-205.

Deesomsak, R., Paudyal, K., \& Pescetto, G. (2004). The Determinants of Capital Structure: Evidence from the Asia Pacific Region. Journal of mutinational financial management, 14, 387-405.

Dickinson, V. (2011). Cash Flow Patterns as a Proxy for Firm Life Cycle. The Accounting Review, 86 (6), 19691994.

Donaldson, G. (1961). Corporate Debt Capacity: A Study of Corporate Debt Policy and the Determination of Corporate Debt Capacity. Harvard Graduate School of Business Administration.

Faff, R., Kwok, W. C., Podolski, E. J., \& Wong, G. (2016). Do corporate policies follow a life-cycle? Journal of Banking \& Finance, 69, 95-107.

Fan, J. P., Titman, S., \& Twite, G. (2012). An International Comparison of Capital Structure and Debt Maturity Choices. The Journal of Financial and Quantitative Analysis, 47 (1), 23-56.

Faulkender, M., Flannery, M. J., Hankins, K. W., \& Smith, J. M. (2012). Cash flows and leverage adjustments. Journal of Financial Economics, 103, 632-646.

Fischer, E. O., Heinkel, R., \& Zechner, J. (1989). Dynamic Capital Structure Choice: Theory and Tests. The Journal of Finance, 44 (1). 
Flannery, M. J., \& Hankins, K. W. (2007). A theory of capital structure adjustment speed.

Flannery, M. J., \& Rangan, K. P. (2006). Partial adjustment toward target capital structures. Journal of Financial Economics, 79 (Elsevier), 469-506.

Goldstein, R., Ju, N., \& Leland, H. (2001). An EBIT-Based Model of Dynamic Capital Structure. The Journal of Business, 74 (4), 483-512.

Hasan, M. M., \& Cheung, A. (.-K. (2018). Organization capital and firm life cycle. Journal of Corporate Finance, 48, 556-578.

Hasan, M. M., Hossain, M., Cheung, A. (.-K., \& Habib, A. (2015). Corporate life cycle and cost of equity capital. Journal of Contemporary Accounting \& Economics, 11, 46-60.

Hennessy, C. A., \& Whitted, T. M. (2005). Debt Dynamics. The Journal of Finance, 60 (3), 1129-1165.

Hirshleifer, J. (1966). Investment Decision Under Uncertainty: Applications of the State-Preference Approach. The Quarterly Journal of Economics, 80 (2), 252-277.

Hovakimian, A., \& Li, G. (2009). Do Firms Have Unique Target Debt Ratios to Which They Adjust? ssrn papers, 1-37.

Hovakimian, A., Opler, T., \& Titman, S. (2001). The Debt-Equity Choice. The Journal of Financial and Quantitative Analysis, 36 (1), 1-24.

Huang, R., \& Ritter, J. R. (2009). Testing Theories of Capital Structure and Estimating the Speed of Adjustment. The Journal of Financial and Quantitative Analysis, 44 (2), 237-271.

Kieschnick, R., \& Moussawi, R. (2018). Firm age, corporate governance, and capital structure choices. Journal of Corporate Finance, 48, 597-614.

Kraus, A., \& Litzenberger, R. H. (1973). A State-Preference Model of Optimal Financial Leverage. The Journal of Finance, 28 (4), 911-922.

Leary, M. T., \& Roberts, M. R. (2005). Do Firms Rebalance Their Capital Structures? The Journal of Finance, 60 (6), 2575-2619.

Matemilola, B. T., Bany-Ariffin, A. N., Azman-Saini, W. N., \& Nassir, A. M. (2018). Does top managers' experience affect firms' capital structure? Research in International Business and Finance, 45, 288-498.

Modigliani, F., \& Miller, M. H. (1963). Corporate Income Taxes and the Cost of Capital: A Correction. The American Economic Review, 53 (3), 433-443.

Modigliani, F., \& Miller, M. H. (1958). The Cost of Capital, Corporation Finance and the Theory of Investment. The American Economic Review, 48 (2), 261-297.

Myers, S. C. (1984). The Capital Structure Puzzle. The Journal of Finance, 39 (3), 575-592.

Shyam-Sunder, L., \& Myers, S. C. (1999). Testing static tradeoff against pecking order models of capital structure. Journal of Financial Economics, 51, 219-244. 
